DOI: 10.15587/2706-5448.2021.229532

Article type «Reports on Research Projects»

\section{Kateryna Kyivska, Svitlana Tsiutsiura}

\title{
IMPLEMENTATION OF ARTIFICIAL INTELLIGENCE IN THE CONSTRUCTION INDUSTRY AND ANALYSIS OF EXISTING TECHNOLOGIES
}

The object of research is the process of using information technology in the construction industry. One of the most problematic areas is increasing the efficiency of the construction industry through the introduction of digital technologies. The research carried out is based on the application of an approach that is implemented using artificial intelligence. The study used machine learning and fuzzy logic methods to mark visual data and analyze it for potential threats, as well as to reduce all possible risks. The main feature of this approach is that using machine learning technology, it is possible to reduce the risks of a project before they affect its profit. So, using artificial intelligence in combination with BIM technologies, it is possible to predict work on construction projects based on real-time data, past activities and other factors in such a way as to optimize construction processes. The benefits to be gained from implementing digital processes will become even more evident in future projects as AI continues to analyze company data. This is due to the fact that the proposed approach using fuzzy logic has a number of features, in particular, the more information machine learning algorithms process, the more complex they become. As a result, they provide even more useful information and allow to make even better decisions. This provides an opportunity to minimize risks and efficiently allocate resources when working on projects. Compared to conventional information technology, artificial intelligence can be used to build a knowledge-based security management system and combine statistical probabilities to help mitigate security risks in construction projects.

Keywords: artificial intelligence, information technology, BIM technology, machine learning, automation of the construction industry.

Kyivska, K., Tsiutsiura, S. (2021). Implementation of artificial intelligence in the construction industry and analysis of existing technologies. Technology Audit and Production Reserves, 2 (2 (58)), 12-15. doi: http://doi.org/10.15587/2706-5448.2021.229532

\section{Introduction}

The construction industry is currently undergoing a transformation from traditional, hierarchically organized construction sites to digital and more autonomous ones. A digital shift is taking place and digital advancement is advancing so rapidly that the industry is struggling to keep up. The introduction of artificial intelligence is a relatively unexplored topic, especially in the construction industry [1]. Artificial intelligence (AI) can automate several operations and improve the efficiency of the construction process [2]. This is consistent with lean thinking, where minimizing waste and maximizing cost is the primary goal of AI adoption. Therefore, it is relevant to analyze artificial intelligence methods with the possibility of their combined use with BIM technologies. Thus, the object of research is the process of using information technology in the construction industry. The aim of research is to show how the construction industry can narrow the gap between the potential benefits and the up-to-date benefits from the AI implementation.

\section{Methods of research}

In order to find a way to close this gap, the following two research questions were developed.

1) What are the potential benefits of implementing artificial intelligence in the construction industry?

2) How is the construction industry benefiting from the introduction of artificial intelligence today?

This study is limited to case studies of a construction project located in Oslo, Norway. The case study is limited to three digital tools. Based on the lack of published research on the AI implementation, document examinations and interviews were selected as specific methods.

The case in question is Bispevika, a construction project in Oslo [3]. The project consists of approximately 7 years of construction and AI implementation in the construction industry, and its impact on human behavior. This project was chosen based on its unconventional way of working with innovative processes and tools. In addition, the choice was influenced by the fact that a project of this scale is an ideal testing ground for implementation 
through the possibility of training and improvement by the same people. The Bispevika mentality is based on a lean approach. To get an idea of the implementation of artificial intelligence, the implementation of three digital tools was considered in more detail (Table 1) [3].

Table 1

Description of selected digital instruments at Bispevika

\begin{tabular}{|c|l|l|l|}
\hline Instrument & \multicolumn{1}{|c|}{ Description } & $\begin{array}{c}\text { Digitization } \\
\text { level }\end{array}$ & $\begin{array}{c}\text { Implementation } \\
\text { phase }\end{array}$ \\
\hline Touchplan & $\begin{array}{l}\text { A web building collaboration } \\
\text { tool that can be thought of as } \\
\text { a digital version of the tools } \\
\text { in LPS (Sensory Plan 2018) }\end{array}$ & Digitization & $\begin{array}{c}\text { Untimely } \\
\text { performance }\end{array}$ \\
\hline Synchro & $\begin{array}{l}\text { 4D digital construction platform } \\
\text { empowers workers to visua- } \\
\text { lize, discuss and collaborate } \\
\text { to find all constraints before } \\
\text { doing (5ynchro 2019) }\end{array}$ & Digitization & Intermediate \\
implementation \\
\hline ALICE & $\begin{array}{l}\text { Artificial intelligence scheduling } \\
\text { software that uses user input to } \\
\text { create and optimize schedules } \\
\text { based on the created methods } \\
\text { (ALICE 2017) }\end{array}$ & Digital \\
conversion & Early testing \\
\hline
\end{tabular}

In order to identify useful experience in the AI implementation in other industries, a number of studies were carried out, which were based on identifying the digital shift and its impact on human behavior [4]

\section{Research results and discussion}

There is a perception that the construction industry is digitalized and has a low level of productivity development compared to other industries. However, research shows that the correct implementation of digitization will increase the efficiency of the construction process. More advanced technologies such as artificial intelligence are now entering the industry [5].

With a more or less complete lack of research looking at the AI implementation, it will be necessary to take advantage of the research results concerning the implementation process itself and combine them with the AI technical knowledge. Document studies and interviews were selected as appropriate data collection methods (Table 2).

Table 2

Description of external interviews

\begin{tabular}{|c|l|l|}
\hline Company & \multicolumn{1}{|c|}{ Company description } & \multicolumn{1}{c|}{ Interview description } \\
\hline $\begin{array}{c}\text { Norwegian } \\
\text { Open AI } \\
\text { lab }\end{array}$ & $\begin{array}{l}\text { A research center that } \\
\text { brings together various } \\
\text { research efforts within the } \\
\text { AI framework }\end{array}$ & $\begin{array}{l}\text { Professor of Computer Science and } \\
\text { Artificial Intelligence }\end{array}$ \\
\hline Inmeta & $\begin{array}{l}\text { Currently, the key research } \\
\text { areas are healthcare, ener- } \\
\text { gy, ocean space, digital } \\
\text { economy and smart envi- } \\
\text { ronment (NTNU 2019) }\end{array}$ & $\begin{array}{l}\text { Extensive experience in the de- } \\
\text { velopment and implementation of } \\
\text { artificial intelligence systems in the } \\
\text { oil and gas industry, gas industry } \\
\text { and fishing }\end{array}$ \\
\hline $\begin{array}{c}\text { Space- } \\
\text { maker }\end{array}$ & $\begin{array}{l}\text { One of the leading machine } \\
\text { learning consulting compa- } \\
\text { nies in Norway (in 2019) }\end{array}$ & $\begin{array}{l}\text { Data scientist with a specialization } \\
\text { in machine learning. Experience in } \\
\text { the development and implementa- } \\
\text { tion of artificial intelligence systems } \\
\text { in the healthcare sector }\end{array}$ \\
\hline
\end{tabular}

Digitization and digital transformation are often referred to as the same thing. However, these words represent different levels of the digital world. Digitizing involves creating a digital version of analog information, such as checklists, on your mobile device instead of paper. Digitization refers to the second level, where machines can perform humancontrolled processes, such as the continuous updating of the building information model (BIM technology) [6, 7]. Digital transformation is the integration of digital technologies in such a way that an organization is fundamentally changing the way they work. AI is defined as using the ability of a machine to mimic the intellectual behavior of a person, thus seeking to use human-developed algorithms for the approximate execution of conditionally complex tasks. The introduction of artificial intelligence can be seen as a digital transformation. The main benefits of AI for organizations are: improving the end-user experience with the data it provides [8]. Automating tasks allows people to focus on work that will add value and reduce human error, and deliver services faster. This can be seen in connection with the principles of lean manufacturing, where maximizing value, minimizing waste and improving the efficiency of the work process are central [9]. As is well known, AI adaptation is relatively low in the construction industry. However, there are several startups today that offer programs related to scheduling and image recognition. Using historical data in addition to human resources, algorithms can look at millions of alternatives for projects and continually improve graphs. Image recognition allows hazardous workers to be identified and aggregated to determine future training and education priorities. However, any AI algorithm is based on learning, not programming, which means that algorithms require a certain amount of data to be executed at the human level. Getting big data is seen today as a limitation for many construction companies. Artificial intelligence can help the construction industry overcome the industry's biggest challenges, including costs, planning and safety. However, the construction industry is now in the early stages of digital transformation, and few projects have actually implemented artificial intelligence. The central question that is considering implementation will be how to achieve successful human-AI collaboration.

The digital shift introduces new ways of working, where people and technology must collaborate. Traditional culture classifies people and technology as separate entities. However, in recent years, technological development has led to the emergence of advanced automation that can respond better than humans in specific situations. Humans can't compete with AI when it comes to analyzing data, information and knowledge, just as AI can't compete with human abilities for pedagogy, creativity, vision and ethics. Since successful cooperation between humans and humans requires certain tasks and responsibilities, then cooperation between humans and artificial intelligence requires the same. Although tasks and responsibilities are split between human and AI, it can be difficult for humans to trust the AI output. How does the AI arrive at a certain prediction and recommendation, and then determine if this is a good decision or not? This is one of the reasons that the adoption of some AI tools remains low in application areas where clarification is useful or really necessary. Trust includes a complex set of interacting factors, including attitudes, beliefs, control, emotions, risk, and 
power. So the AI has no attitudes, beliefs or emotions, this can lead to the fact that it will be difficult for a person to trust the result. The person is in a vulnerable position. However, if vulnerability is defined as ability (opportunity, intention), and it is assumed that the intention of the AI coincides with the intention of the person, then people can study the capabilities of the AI through training. In other words, transparency and trust can be increased by teaching people what AI can and can't do, and where violation can occur. However, what happens if humans and artificial intelligence disagree? Fluid interaction, which allows the person to edit the AI, and the AI to guide the person, will be imperative. The goal is to enable collaborative data exploration, leading to a common framework where AI and human beliefs have been updated. The interaction that allows AI to answer such questions as «why do I need to change my plan at this time?» will increase a person's ability to find biased data and understand and trust AI. Another important factor in trust is time. If the machine runs reliably and predictably for a long time, people will begin to trust AI as much as they trust other people.

The follow-up and findings are based on three external interviews with a high level of AI knowledge and nine case studies with a relatively low level of AI knowledge. The remaining eight respondents on specific cases are not included in the study due to their lack of knowledge about AI. The interviewees were asked an open-ended question that looks at the future of artificial intelligence in the construction industry to reflect people's thoughts on the digital future of construction. This question led to both examples of use and possible consequences. In analyzing the collected data, applications were divided into three categories of AI: machine learning, pattern recognition, and automation. Machine learning [10] consists of algorithms that can analyze data and develop new solutions based on historical figures. Pattern recognition is the process of pattern recognition using a machine learning algorithm. Automation is the process by which AI will be able to perform tasks that are first performed by humans, or tasks that are beyond human capabilities [11]. Table 3 presents the structure of the polls for these three categories [4].

All AI categories in Table 3 will affect the workflow and work tasks. The industry today puts trust in individual expertise over empiricism.

However, to prove the possible benefits of artificial intelligence in the construction industry, a study was conducted on the implementation of three digital tools: Touchplan, Synchro and ALICE [12].

Touchplan is a construction planning tool that takes this technology collaboration to the next level. The main goal of the tool is to create exceptional teams that deliver impressive projects - ones that run smoothly, complete on time or ahead of schedule, and use the collective intelligence of the entire team to learn and solve problems every day.

Synchro is a $4 \mathrm{D}$ digital construction platform that gives workers the ability to visualize, discuss and collaborate to find all constraints before completing projects. As with Touchplan, there is currently no specific $4 \mathrm{D}$ planning training strategy or training in Synchro. The main advantage is the use of the $4 \mathrm{D}$ model to gain a general understanding of work tasks. This model is especially useful in terms of the diversity of languages at the construction site.
Table 3

Future applications of artificial intelligence presented by the Bispevika team

\begin{tabular}{|c|c|c|}
\hline AI category & Application & Influence \\
\hline $\begin{array}{l}\text { Machine } \\
\text { learning }\end{array}$ & Planning & $\begin{array}{l}\text { Analysis of large amounts of data based } \\
\text { on historical figures and human con- } \\
\text { tributions. Evaluates millions of layouts } \\
\text { that take exponentially more time for } \\
\text { people to complete }\end{array}$ \\
\hline $\begin{array}{c}\text { Pattern } \\
\text { recognition }\end{array}$ & $\begin{array}{l}\text { Health, safety and } \\
\text { labor protection, } \\
\text { environment }\end{array}$ & $\begin{array}{l}\text { Prediction/early detection of dange- } \\
\text { rous situations using machine learn- } \\
\text { ing algorithms combined with pattern } \\
\text { recognition }\end{array}$ \\
\hline $\begin{array}{c}\text { Pattern } \\
\text { recognition }\end{array}$ & Warehouse space & $\begin{array}{l}\text { Digital map that constantly shows where } \\
\text { and where materials or machines can } \\
\text { be stored. Improves predictability and } \\
\text { efficiency in the field }\end{array}$ \\
\hline Automation & $\begin{array}{l}\text { Jobs doing } \\
\text { hazardous work }\end{array}$ & $\begin{array}{l}\text { For example, work at height. Fire pro- } \\
\text { tection of steel beams. Increase the } \\
\text { safety of people }\end{array}$ \\
\hline Automation & $\begin{array}{l}\text { Self-propelled } \\
\text { construction equip- } \\
\text { ment }\end{array}$ & $\begin{array}{l}\text { The use of robots and self-propelled } \\
\text { construction equipment will change the } \\
\text { workflow }\end{array}$ \\
\hline Automation & Quality assurance & $\begin{array}{l}\text { The jobs that travel around the con- } \\
\text { struction site scan the situation on site } \\
\text { and compare it to the BIM project. This } \\
\text { technology can save hundreds of hours } \\
\text { spent on quality }\end{array}$ \\
\hline
\end{tabular}

Touchplan and Synchro are transparent technology in which a person controls how an input signal is converted into an output signal. The result of a human-driven process that makes the process transparent means a simple and reliable result. However, there is no guarantee that it is the most optimized, for example, in terms of progress, staffing and cost, since the human brain has a limited ability to see possibilities.

ALICE is an artificial intelligence-based construction platform that uses AI to analyze the flow of labor and equipment across the entire jobsite. This technology allows users to explore different construction plans in real time and understand the impact of key building decisions on the cost and duration of a project.

\section{Conclusions}

The study confirmed the high potential of using artificial intelligence and machine learning in the construction industry. The implementation of the proposed approaches will improve the efficiency of construction, its safety and quality. To realize the potential of big data in construction through machine learning and artificial intelligence algorithms, it is necessary to accumulate a critical mass of data on various construction projects and integrate various information systems of construction companies. The results of the study will be useful in the standardization of construction processes and the processing of data on construction projects.

In the course of further research, it is planned to consider the introduction of artificial intelligence, taking into account the needs of users, based on the collection of empirical data and the study of experience gained from other industries. 


\section{References}

1. Casebeer, W. D.; Masakowski, Y. R. (Ed.) (2020). Building an Artificial Conscience: Prospects for Morally Autonomous Artificial Intelligence. Artificial Intelligence and Global Security. Bingley: Emerald Publishing Limited, 81-94. doi: http://doi.org/ 10.1108/978-1-78973-811-720201005

2. Sacha, D., Sedlmair, M., Zhang, L., Lee, J. A., Peltonen, J., Weiskopf, D., Keim, D. A. et. al. (2017). What you see is what you can change: human-centered machine learning by interactive visualization. Neurocomputing, 268, 164-175. doi: http:// doi.org/10.1016/j.neucom.2017.01.105

3. Hunn, L. K., Fyhn, H.; Pasquire, C., Hamzeh, F. R. (Ed.) (2019). Building and Sustaining a Culture with a Mindset for Disruptive Performance: A Case Study from Bispevika Norway. Proc. 27-th Annual Conference of the International. Dublin: Group for Lean Construction (IGLC), 369-378. doi: http://doi.org/10.24928/2019/0172

4. Walday, M., Olsgard, F. (2004). Ny senketunnel I Bjørvika. Biologiske forundersøkelser $i$ November 2003. Rapport 0-VK-203, 30.

5. Terentiev, O. O., Balina, O. I., Shabala, Ye. Ye., Turushev, O. S. (2016). Model definition of physical deterioration of structural elements the building for the tasks of diagnostics of technical condition. Management of Development of Complex Systems, 26, 153-157

6. Kyivska, K. I., Tsiutsiura, S. V., Tsiutsiura, M. I., Kryvoruchko, O. V., Yerukaiev, A. V., Hots, V. V. (2019). A study of the concept of parametric modeling of construction objects. International Journal of Advanced Research in Engineering and Technology, 10 (2), 636-646. doi: http://doi.org/10.34218/ijaret.10.2.2019.060

7. Terentyev, O., Tsiutsiura, M. (2015). The Method of Direct Grading and the Generalized Method of Assessment of Build ings Technical Condition. International Journal of Science and Research, 4 (7), 827-829.
8. Mikhailenko, V. M., Terentiev, O. O., Shabala, Ye. Ye., Kyivska, K. I., Horbatiuk, Ye. V. (2017). Modeli, metody ta informatsiina tekhnolohiia diahnostyky tekhnichnoho stanu budivelnykh konstruktsii $i$ sporud. Kyiv: TsP «Komprynt», 161.

9. Terentyev, O., Bohdan, M. (2015). The Method of Prediction of Deformations of Buildings and FIlure Analysis the Examination of Technical Condition of Buildings. International Journal of Science and Research, 4 (8), 280-282.

10. Terentyev, O., Poltorak, O. (2017). Risk assessment of delayed damage diagnostics of technical condition of building structures. ScienceRise, 2 (31), 42-45. doi: http://doi.org/10.15587/23138416.2017.93907

11. Terentyev, O., Poltorak, O. (2016). Development of models and methods for determining the physical deterioration of items for the task of diagnostics of technical condition of buildings and structures. ScienceRise, 8 (2 (25)), 14-19. doi: http://doi.org/ 10.15587/2313-8416.2016.76318

12. Abbass, H. A. (2019). Social Integration of Artificial Intelligence: Functions, Automation Allocation Logic and Human-Autonomy Trust. Cognitive Computation, 11 (2), 159-171. doi: http:// doi.org/10.1007/s12559-018-9619-0

Kateryna Kyizska, PhD, Associate Professor, Department of Information Technology, Kyiv National University of Construction and Architecture, Kyiv, Ukraine, ORCID: https://orcid.org/0000-00030906-1128, e-mail: kievkatya77@gmail.com

Svitlana Tsiutsiura, Doctor of Technical Sciences, Professor, Department of Information Technology, Kyiv National University of Construction and Architecture, Kyiv, Ukraine, ORCID: https://orcid.org/ 0000-0002-4270-7405, e-mail: svtsutsura@gmail.com 